Dhanan Sarwo Utomo, Bhakti Stephan Onggo, Stephen Eldridge, Applications of agent-based modelling and simulation in the agri-food supply chains, In European Journal of Operational Research, 2017, ISSN 0377-2217, https://doi.org/10.1016/j.ejor.2017.10.041.

\title{
Applications of Agent-Based Modelling and Simulation in the Agri-Food Supply Chains
}

\author{
Dhanan Sarwo Utomo ${ }^{1}$, Bhakti Stephan Onggo ${ }^{2}$, Stephen Eldridge ${ }^{1}$ \\ ${ }^{1}$ Department of Management Science, Lancaster University Management School, Lancaster \\ University, Lancaster LA1 4YX \\ ${ }^{2}$ Trinity Business School, Trinity College Dublin, The University of Dublin, Republic of Ireland
}

\begin{abstract}
Agri-food supply chains (ASC) are an important application domain for Operational Research/Management Science. In particular, the use of agent-based simulation (ABS) has increased in ASC research in recent years. This paper reviews existing ASC research that use ABS. The review begins by analysing the characteristics of the models and modelling reported in the literature. It illustrates that existing modelling research features extensive use of: single echelon supply chains; cases from high and middle income countries; unprocessed food products, empirical (as opposed to hypothetical) data; decision-making related to production planning and investment; and the use of black box validation. The second part of the review uses bibliographic mapping to analyse areas in ASC research which are yet to be addressed using ABS. We find that areas such as collaboration and competition, buyer-seller relationships, and service are underresearched. In addition, key actors in ASC such as food processors, supermarkets and retailers have not been included in the ABS models reported. Furthermore, these models have yet to incorporate important supply chain management theories such as Transaction Cost Economics and Resource-Based View as part of their design.
\end{abstract}

Keywords: Literature review, Agent-based modelling, Agri-food supply chain, bibliographic mapping

\section{Introduction}

Agri-food supply chains (ASC) comprise a network of heterogeneous actors working together in different processes and activities to deliver products and services to the market and satisfy customers' demands. Actors in ASC include various organisations from producers, distributors, processors and consumers (Ahumada and Villalobos, 2009, Higgins et al., 2010, Pla et al., 2014, Borodin et al., 2016). The actors in ASC do not usually form linearly integrated businesses (Kutcher and Norton, 1982, Higgins et al., 2010). They have a high degree of autonomy with objectives that may conflict with those of the other actors. Consequently, this limited perspective makes it difficult for them to envisage how their individual decisions may affect the performance of the whole supply chain (Higgins et al., 2010)). Furthermore, the dynamics in ASC are often influenced by social factors (e.g. lifestyles, personal values, safety concerns) (Busby and Onggo, 2013, Busby et al., 2016, Chebolu-Subramanian and Gaukler, 2015), economic factors (e.g. price) and the environment (e.g. climate variability) (Borodin et al., 2016)). Actors in ASC have to adapt to these external factors in order to survive. In the light of these characteristics, it is not surprising 
Dhanan Sarwo Utomo, Bhakti Stephan Onggo, Stephen Eldridge, Applications of agent-based modelling and simulation in the agri-food supply chains, In European Journal of Operational Research, 2017, ISSN 0377-2217, https://doi.org/10.1016/j.ejor.2017.10.041.

that some authors (e.g., Ahumada and Villalobos (2009)) argue that ASC are complex and hard to manage.

The complexities of ASC have attracted the interest of Operational Research and Management Science (OR/MS) researchers since the late 1940s (Borodin et al., 2016) and they have been the subject of a number of reviews. Ahumada and Villalobos (2009) reviewed the application of mathematical models in agricultural production and distribution planning while Janssen and van Ittersum (2007) reviewed the use of optimisation models (known as bio-economic farm model in the agriculture literature) to assess farm innovations and responses to policies. More recently, Soto-Silva et al. (2016) reviewed the applications of OR/MS methods in fresh fruit supply chain and Borodin et al. (2016) reviewed the methods to handling uncertainty in ASC. The OR/MS techniques in these reviews include Agent-Based Simulation (ABS) and the benefits of using ABS in ASC have been highlighted by a number of authors (e.g., Higgins et al. (2007), Nolan et al. (2009), Higgins et al. (2010), Krejci and Beamon (2012) and Pla et al. (2014)).

In common with other OR/MS techniques, $\mathrm{ABS}$ is being continually developed and enhanced. Our paper provides a review of the ABS methods used in ASC in order to identify topics in ASC that merit further research using ABS. Our review is complementary to earlier reviews of the application of ABS in related agriculture fields. These include the environment (Kelly et al., 2013), climate adaptation (Berger and Troost, 2014) and land use (Robinson et al., 2007, Matthews et al., 2007). Furthermore, we demonstrate how bibliographic mapping can supplement a conventional literature review to identify research opportunities for the application OR/MS techniques.

Initially, we describe our literature search methodology (in Section 2). We then present an overview of the application of ABS in ASC based on our literature review and discuss the models and modelling approaches reported. In particular, the modelling objectives, application context, models (inputs, outputs, actors, rules and interactions), output analysis, experimentation, validation and model representation are discussed (in Section 3). Subsequently, we present a bibliographic mapping analysis and discuss the ASC topics that are yet to be addressed by ABS researchers (in Section 4). Finally, we present the conclusions of this literature review in section 5.

\section{Method}

The literature search employed the following databases: ABI/INFORM, Academic Search Complete, Business Source Complete, Science Direct and Web of Science. We restricted the search to articles published in international peer-reviewed journals that were written in English and published before February 2016. The keywords used in literature search and the results returned from the search are presented in Table 1 . The keyword search was applied to the content of the articles (i.e., not limited to title and abstract only).

The approach taken for the literature review is illustrated in Figure 1 using a PRISMA four-phase flow-diagram (Moher et al., 2009, Vrabel, 2015). It begins with Dataset D from Table 1. Dataset D contains articles relating to ASC. Duplicate articles along with editorials, news, announcements, 
Dhanan Sarwo Utomo, Bhakti Stephan Onggo, Stephen Eldridge, Applications of agent-based modelling and simulation in the agri-food supply chains, In European Journal of Operational Research, 2017, ISSN 0377-2217, https://doi.org/10.1016/j.ejor.2017.10.041.

proceedings and dissertations were removed to create dataset D1 comprising 16,538 articles. Dataset D1 would be used for the bibliographic mapping analysis and did not require further filtering.

Table 1: Keywords used in database searching and the number of returned articles

\begin{tabular}{|c|c|c|c|c|c|c|c|}
\hline Code & Keywords & $\begin{array}{l}\text { ABI / } \\
\text { INFORM }\end{array}$ & $\begin{array}{l}\text { Academic } \\
\text { Search } \\
\text { Complete }\end{array}$ & $\begin{array}{l}\text { Business } \\
\text { Source } \\
\text { Complete }\end{array}$ & $\begin{array}{l}\text { Science } \\
\text { Direct }\end{array}$ & $\begin{array}{l}\text { Web of } \\
\text { Science }\end{array}$ & Total \\
\hline$A$ & $\begin{array}{l}\text { ("agent based" } \\
\text { OR "multi } \\
\text { agent") AND } \\
\text { ("simulation" } \\
\text { OR } \\
\text { (“modelling" } \\
\text { OR } \\
\text { "modelling")) }\end{array}$ & 6,360 & 5,029 & 2,014 & 27,148 & 11,885 & 41,736 \\
\hline B & $\begin{array}{l}\text { "supply chain" } \\
\text { OR "supply } \\
\text { chains" }\end{array}$ & 44,606 & 9,774 & 23,230 & 43,972 & 23,100 & 144,682 \\
\hline C & $\begin{array}{l}\text { "agriculture" } \\
\text { OR } \\
\text { "agricultural" } \\
\text { OR "food" OR } \\
\text { "agri-food" OR } \\
\text { "livestock" OR } \\
\text { "fisheries" }\end{array}$ & 276,808 & $1,139,158$ & 116,263 & $1,877,194$ & 716,254 & $4,125,677$ \\
\hline D & B AND C & 13,608 & 2,000 & 1,849 & 16,035 & 2,444 & 35,936 \\
\hline
\end{tabular}

From dataset D1, we searched for articles on ABS applications in ASC (i.e., using keyword "A and $\left.D^{\prime \prime}\right)$. The number of articles retained was 251 . These articles were then screened individually to ensure relevance using the following the following criteria. Firstly, the article must be accessible to the wider academic community. Secondly, the article must feature a complete ABS model rather than simply an unimplemented conceptual ABS model. Thirdly, we excluded literature review papers. Fourthly, we excluded articles that focus only on nonhuman actors and articles in which the keywords only appear in the reference section. Finally, the article must address research questions related to supply chain topics (e.g., processes and production systems, inventory management, demand management and improving the performance in the supply chain (Oliveira et al., 2016) and include one or more ASC actors (e.g., producers, harvesting \& transport, food processor \& storage, packaging \& handling, distributors, retailers, consumers, and waste management). Similar to Cunningham (2001), Da Silva and de Souza Filho (2007), Webber and Labaste (2009) and Higgins et al. (2010), we include articles that discuss livestock, crops, fisheries, and food products in our agri-food supply chain review. Using these screening 
Dhanan Sarwo Utomo, Bhakti Stephan Onggo, Stephen Eldridge, Applications of agent-based modelling and simulation in the agri-food supply chains, In European Journal of Operational Research, 2017, ISSN 0377-2217, https://doi.org/10.1016/j.ejor.2017.10.041.

criteria, 15 articles were retained. Next, we conducted backwards and forward citation analysis from these articles using Google Scholar and Web of Science. After applying the same screening criteria, the number of articles increased to 58. These comprise dataset D2 that was used for our review.

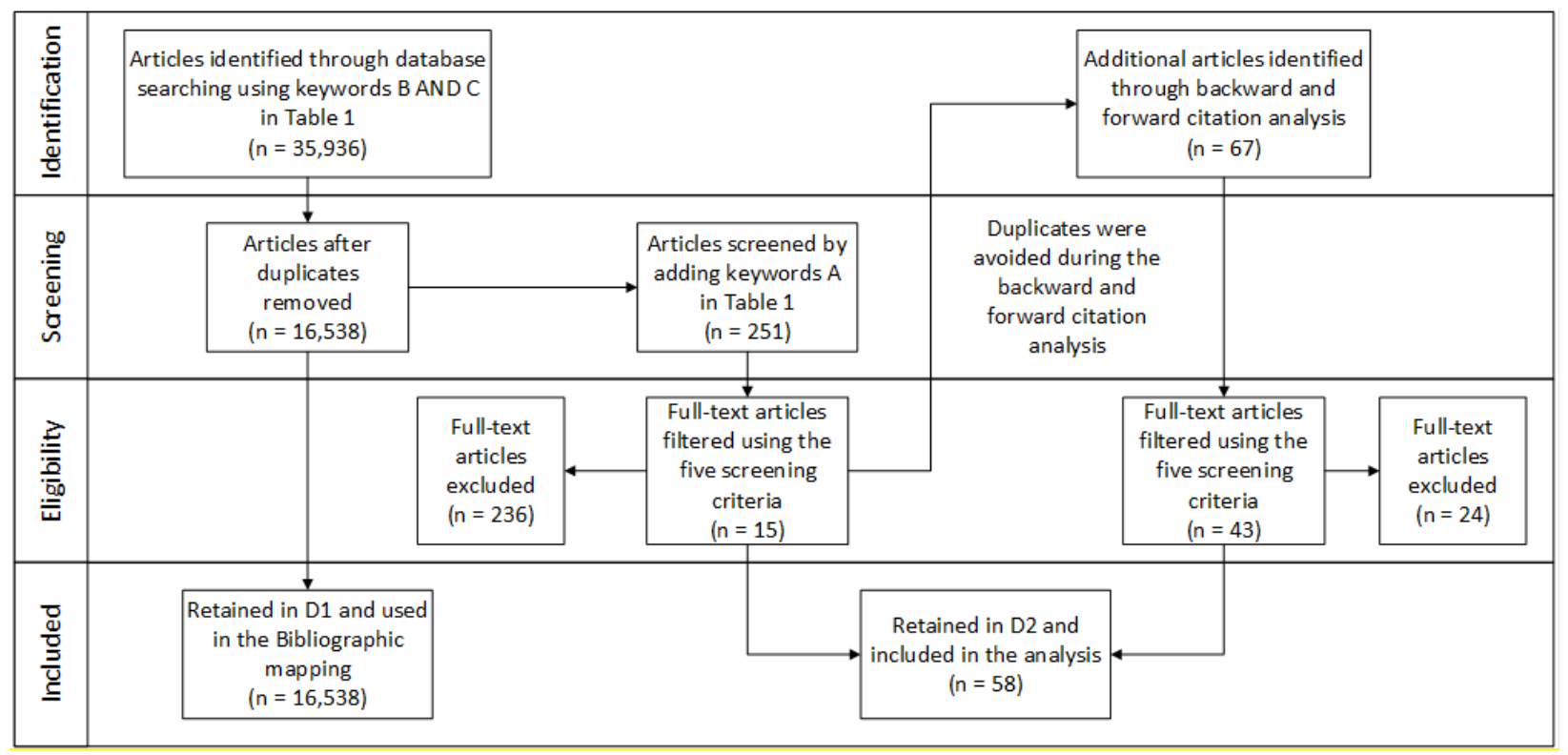

Figure 1 PRISMA flow diagram of the data collection process

\section{Agent-based simulation applications in agri-food supply chain}

This section provides a summary of research into the application of ABS in ASC based on dataset D2. As shown in Figure 2, the number of articles reporting on the application of ABS in ASC has been increasing, especially during the last four years (2013-2016). These articles are published in a variety of journals in the fields of environmental science, agriculture, computer science and operational research (see Table 2). 
Dhanan Sarwo Utomo, Bhakti Stephan Onggo, Stephen Eldridge, Applications of agent-based modelling and simulation in the agri-food supply chains, In European Journal of Operational Research, 2017, ISSN 0377-2217, https://doi.org/10.1016/j.ejor.2017.10.041.

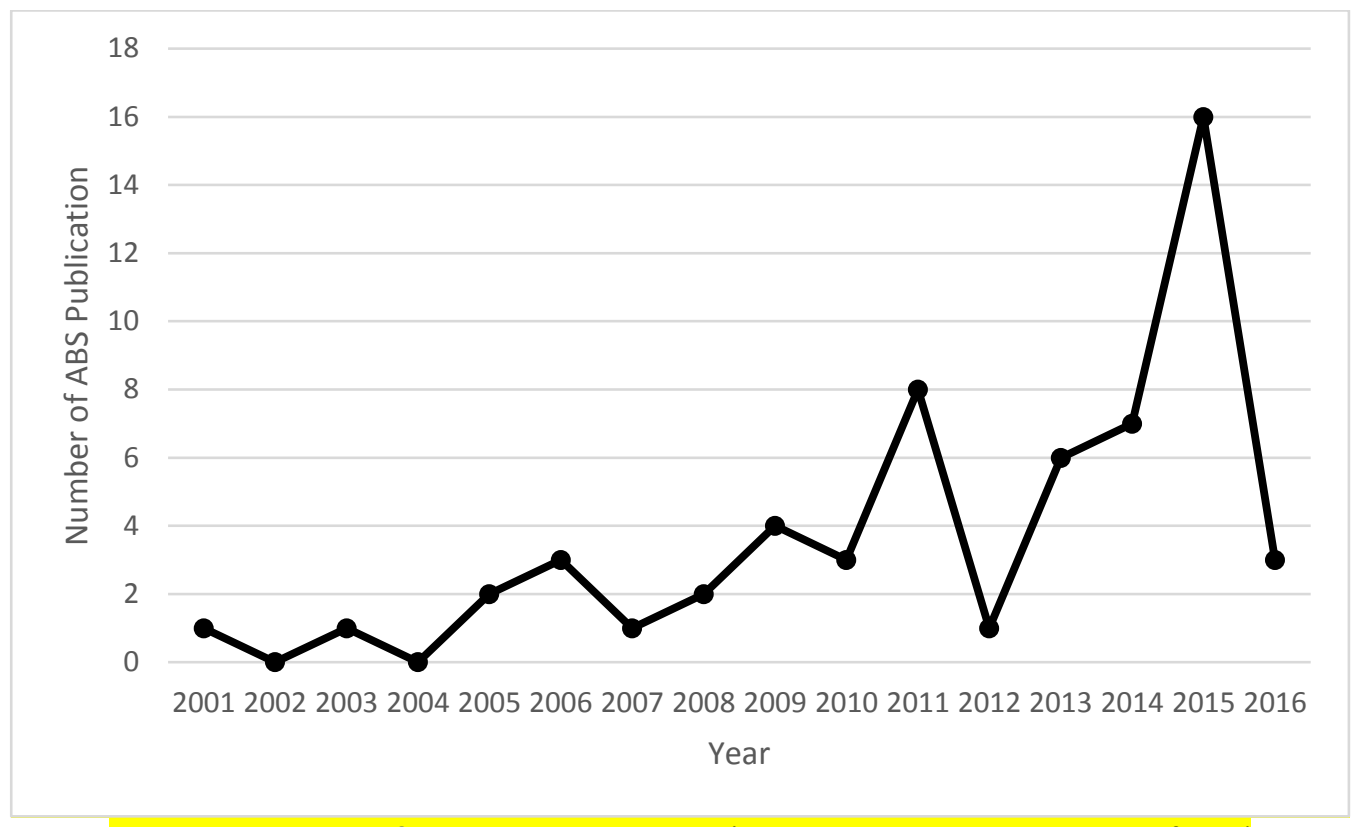

Figure 2: Publication of ABS application per year (2016 contains two-month worth of data)

The most active discussion on this topic takes place in environmental science journals (e.g., Ecological Economics, Ecological Modelling, Ecology and Society, Environmental Modelling \& Software and Environmental Science \& Policy) and agriculture journals (e.g., Agricultural Economics, Agricultural Systems, American Journal of Agricultural Economics, Canadian Journal of Agricultural Economics). Although ASC is an important and interesting application domain for $A B S$, the number of publications in OR/MS specific journals is relatively low. One of the possible explanations is that many authors have focused on ASC specific research questions and ABS is used as a modelling tool to answer those questions. Hence, it makes more sense to discuss the findings in domain-specific journals such as environmental science and agriculture.

Table 2: Distribution of journals that publish ABS applications in ASC

\begin{tabular}{|l|c|}
\hline \multicolumn{1}{|c|}{ Journal Type } & Number of papers (percentage) \\
\hline Environmental science & $23(39.65 \%)$ \\
\hline Agriculture & $20(34.48 \%)$ \\
\hline Computer science & $7(12.06 \%)$ \\
\hline Operational research & $1(1.72 \%)$ \\
\hline Other & $7(12.06 \%)$ \\
\hline
\end{tabular}

\subsection{Research context}

This section explores the context of the research reported in the literature. The studies were divided into real and hypothetical cases and Table 3 shows that most studies use real cases. The real cases were subdivided into categories based on the geographical location and the economic 
Dhanan Sarwo Utomo, Bhakti Stephan Onggo, Stephen Eldridge, Applications of agent-based modelling and simulation in the agri-food supply chains, In European Journal of Operational Research, 2017, ISSN 0377-2217, https://doi.org/10.1016/j.ejor.2017.10.041.

development level of the country as described by the World Bank (2016) (i.e., high income, middle income and low income). Most of the studies took place in Europe (35.7\%) and Asia (25\%) and in high income (57.7\%) and middle income (36.5\%) countries. This geographical and economic development categorization is important because empirical evidence suggests that ASC actors from different geographical regions or different economic development levels may behave differently. For example, differences in contract farming participation between people living in Ghana, India, Madagascar, Mozambique and Nicaragua are noted (Barrett et al., 2012). Furthermore, Meijer et al. (2006) observe the differences in preference when choosing transaction governance mechanisms (i.e., market, hierarchy and network) which could be explained by different cultural backgrounds. Similarly, Godfray et al. (2010) explain different practices in developed and developing countries associated with food waste production. This suggests that a need to extend the reach of ABS research in ASC, particularly in low income countries.

Table 3: Summary of the research context

\begin{tabular}{|l|l|r|}
\hline Classification & Category & Number of papers \\
\hline \multirow{4}{*}{ Types of case study } & Real case & 52 \\
\cline { 2 - 3 } & Hypothetical case & 6 \\
\hline \multirow{4}{*}{ Geographical context } & Africa & 6 \\
\cline { 2 - 3 } & Asia & 14 \\
\cline { 2 - 3 } & Australia & 3 \\
\cline { 2 - 3 } & Europe & 20 \\
\cline { 2 - 3 } & North America & 7 \\
\cline { 2 - 3 } & South America & 6 \\
\hline \multirow{4}{*}{$\begin{array}{l}\text { Economic Development } \\
\text { agricultural products } \\
\text { modelled }\end{array}$} & High-Income countries & 30 \\
\cline { 2 - 3 } & Middle-Income Countries & 19 \\
\cline { 2 - 3 } & Low-Income Countries & 3 \\
\hline \multirow{2}{*}{$\begin{array}{l}\text { Type of food and } \\
\text { agricultural products }\end{array}$} & Single products & 35 \\
\cline { 2 - 3 } & Multiple products & 50 \\
\cline { 2 - 3 } & & Processed product \\
\hline
\end{tabular}

Alternative classifications of the real cases were also adopted relating to the number of different food and agricultural products that were studied. This classification is important because the number of products affects the modelling techniques used. This will be discussed further in section 3.4. As shown in Table 3, the majority of the existing studies incorporate various food and agricultural products. Table 3 also shows that the studies predominantly feature fresh or unprocessed food products. 
Dhanan Sarwo Utomo, Bhakti Stephan Onggo, Stephen Eldridge, Applications of agent-based modelling and simulation in the agri-food supply chains, In European Journal of Operational Research, 2017, ISSN 0377-2217, https://doi.org/10.1016/j.ejor.2017.10.041.

\subsection{Research objectives}

This section discusses the objectives of research in ASC that uses ABS as the main modelling method. The research objectives can be categorized into theory development (i.e., to explain ASC phenomena or to test a theory in the context of ASC), methodology development (i.e., to improve existing methods or to propose new methods for $A B S$ in the context of ASC) or policy development (i.e., to predict or to analyse the impact of a management/policy decision). As shown in Table 4, all three types of objective feature in dataset D2 and it should be noted that a paper could contribute in more than one category. Interestingly, between 2001 and 2005, most ABS applications focused on theoretical contribution while in more recent years, between 2011 and early 2016, ABS applications for policy development (38.3\%) and methodology development (36.2\%) studies become increasingly popular.

Table 4: Classification based on the type of research objectives

\begin{tabular}{|l|c|c|c|c|}
\hline \multicolumn{1}{|c|}{$\begin{array}{c}\text { Research } \\
\text { Objectives }\end{array}$} & 2001-2005 & 2006-2010 & 2011-early 2016 & Total \\
\hline $\begin{array}{l}\text { Theory } \\
\text { development }\end{array}$ & 4 & 6 & 12 & 22 \\
\hline $\begin{array}{l}\text { Methodology } \\
\text { development }\end{array}$ & 0 & 1 & 17 & 18 \\
\hline Policy development & 1 & 5 & 18 & 24 \\
\hline
\end{tabular}

One typical research objective in the theory development category is to build a model to explain the behaviour of agents and its consequence (e.g., Becu et al. (2003), Bharwani et al. (2005), Tykhonov et al. (2008), Ross and Westgren (2009), Zhang and Brorsen (2010), Graubner et al. (2011), Udumyan et al. (2014), Krejci et al. (2016), Malawska and Topping (2016)). Another popular research objective is to build a model that explains the impact of decisions by individual agents on the dynamics of a supply chain's structure. These include: the emergence of diversity; the dynamics of cooperation networks; the formation of clusters; and change in market power (e.g., Castella et al. (2005a), Ng (2008), Følgesvold and Prenkert (2009), Bert et al. (2011), Boero (2011), Ross (2011), Boyer and Brorsen (2013), Bakker et al. (2015), Krejci and Beamon (2015), Albino et al. (2016)). There is also a significant number of studies related to how innovation is adopted and spread among ASC actors (e.g., Berger (2001), Kaufmann et al. (2009), Olabisi et al. (2015)).

The methodological papers propose either new or improved methods in ABS using ASC case studies with a view to possible extensions beyond ASC. Methodological developments are proposed in a range of topics including: agent's decision-making rules (e.g., Schreinemachers and Berger (2011) and Morgan et al. (2015)); simulation parameterization (e.g., Berger and Schreinemachers (2006), Schreinemachers et al. (2009), Nainggolan et al. (2012), Troost and Berger (2015), Zimmermann et al. (2015)); sensitivity analysis (e.g., Schouten et al. (2014), Brändle et al. (2015)); model validation (e.g., Smajgl et al. (2011), Bert et al. (2014), Kaye-Blake 
Dhanan Sarwo Utomo, Bhakti Stephan Onggo, Stephen Eldridge, Applications of agent-based modelling and simulation in the agri-food supply chains, In European Journal of Operational Research, 2017, ISSN 0377-2217, https://doi.org/10.1016/j.ejor.2017.10.041.

et al. (2014), Ge et al. (2015a)); and hybrid modelling approaches (e.g., Happe et al. (2011), Aurbacher et al. (2013), Marohn et al. (2013), Reidsma et al. (2015)).

In the policy development category, most of the studies focus on finance or the use of new technology and innovation. Financial policy is the most popular including aspects such as: credit (e.g., Berger et al. (2006), Schreinemachers et al. (2007), Wossen and Berger (2015), Schreinemachers et al. (2009)); payment schemes (e.g., Happe et al. (2006), Uthes et al. (2011), Schouten et al. (2013), Brändle et al. (2015)); incentives and subsidies (e.g., Smajgl et al. (2011), Quang et al. (2014), Zheng et al. (2015)); pricing (e.g., Morgan and Daigneault (2015)); and compensation schemes (e.g., Troost and Berger (2015)). Policies related to technological and innovation policies include the use of: fertilizers (Berger et al., 2006, Schreinemachers et al., 2007); improved seed (Schreinemachers et al., 2007); tree crop innovations (Schreinemachers et al., 2010); organic agriculture (Gagliardi et al., 2014); and technology standards (Zheng et al., 2015)). There are a number of smaller groups of research related to policy making such as how supply chain actors should cooperate to adapt to climate change (Wang et al., 2013)) or minimise the risk of bioterrorist attack (Chaturvedi et al., 2014). Other studies explore: suitable inspection policies to improve product quality (Ge et al., 2015b, Ge et al., 2015a) or food safety (McPheeKnowles, 2015); appropriate harvesting management plans (Worrapimphong et al., 2010); and policies for manure handling (Zheng et al., 2013) or animal welfare (Osinga et al., 2015).

Research in the policy category can be further divided into categories based on the scope of the policies. Julka et al. (2002) propose that the scope of supply chain policies can be classified into: intra-enterprise policies that cover departments within an organisation and their interface with other organisations; inter-enterprise policies that cover an organisation and its supply chain; and cluster policies that cover all industries in a sector including their suppliers and customers and government. Table 5 shows that the majority of the studies have focused on the cluster category (please note that a paper may analyse more than one policy scope).

Table 5: Classification based on policy scope

\begin{tabular}{|l|c|}
\hline Scope of policy & Number of Paper (percentage) \\
\hline Intra-enterprise & 5 \\
\hline Inter-enterprise & 5 \\
\hline Cluster & 16 \\
\hline
\end{tabular}

\subsection{Data}

This section discusses the input data (for ABS development) and output data (collected during the simulation experiment) used by the models featuring in the studies. Table 6 shows that most of the input data are empirical. The most popular empirical data sources are from secondary sources such as Farm Accountancy Data Network (FADN) and agricultural census data (e.g., Happe et al. (2006), Happe et al. (2011), Zimmermann et al. (2015)). These types of publicly 
Dhanan Sarwo Utomo, Bhakti Stephan Onggo, Stephen Eldridge, Applications of agent-based modelling and simulation in the agri-food supply chains, In European Journal of Operational Research, 2017, ISSN 0377-2217, https://doi.org/10.1016/j.ejor.2017.10.041.

available data are usually presented in aggregate owing to confidentiality concerns. Aggregated data poses a challenge to ABS modelling when generating a representative population though approaches such as that proposed by Troost and Berger (2015) can mitigate this limitation. Hypothetical data are used when researchers build a stylised model to test theories (e.g. Krejci and Beamon (2015)) or when empirical data are difficult to collect (e.g. food contamination (McPhee-Knowles, 2015)).

Table 6: Input and output data

\begin{tabular}{|c|c|c|}
\hline Classification & Category & $\begin{array}{c}\text { Number of } \\
\text { papers }\end{array}$ \\
\hline \multirow[t]{2}{*}{ Data type } & Hypothetical data & 10 \\
\hline & Empirical data & 48 \\
\hline \multirow[t]{4}{*}{ Input data source } & Secondary data & 38 \\
\hline & Primary: Survey & 18 \\
\hline & Primary: Interview & 11 \\
\hline & Primary: Participatory Modelling & 6 \\
\hline \multirow[t]{5}{*}{ Output data } & Production measures & 24 \\
\hline & Financial measures & 22 \\
\hline & Environmental measures & 12 \\
\hline & Trust \& relationship among agents & 5 \\
\hline & Quality \& safety & 4 \\
\hline
\end{tabular}

ABS can be used to produce and analyse various output data relevant to ASC as shown in Table 6. Output data related to production, finance and environment described in the papers can be easily measured and this reflects the prevalence of their use in ABS studies. However, output data related to trust, relationship, quality and safety are more difficult to measure objectively and, similarly, these measures are considered to be more difficult to model (Tykhonov et al., 2008). Nevertheless, ABS is being used to model both types of measures.

The most popular output data related to aspects of production such as yield and produced quantity (e.g., Bharwani et al. (2005), Happe et al. (2006), Berger and Schreinemachers (2006), Zheng et al. (2013), Zimmermann et al. (2015)) and finance such as income and wealth (e.g., Berger (2001), Becu et al. (2003), Bharwani et al. (2005), Berger et al. (2006), Schreinemachers et al. (2007), Marohn et al. (2013)). Examples of model that produce environmental metrics include Schreinemachers et al. (2009), Uthes et al. (2011) and Quang et al. (2014)). Examples of models that use difficult-to-measure output data include: trust and honesty, measured using a probability (Tykhonov et al., 2008); the stability of symbiotic relationship, measured by relationship duration (Albino et al., 2016); cooperation, measured by how many times agent decide to work together with others (Krejci and Beamon, 2015, Boero, 2011); and inspection quality, measured by the probability of product misclassification (Ge et al., 2015a, Ge et al., 2015b). 
Dhanan Sarwo Utomo, Bhakti Stephan Onggo, Stephen Eldridge, Applications of agent-based modelling and simulation in the agri-food supply chains, In European Journal of Operational Research, 2017, ISSN 0377-2217, https://doi.org/10.1016/j.ejor.2017.10.041.

\subsection{Agents, their decision-making rules and their interactions}

In this section, we discuss the key model design features (i.e., agents and their rules for decisionmaking and interactions) used in the studies. Actors in ASC include producers, post-harvest processors, retailers, consumers and others (e.g., Higgins et al. (2010), Pla et al. (2014), Borodin et al. (2016)). Table 7 shows that the producer (i.e., farmer) is included in most ABS models because it is considered the most important actor, especially in agriculture and environmental science journals. This can also explain why the existing reported studies focus on unprocessed agricultural products (see Table 3).

Table 7 shows that the scope of most ABS models is one echelon. This is likely to reflect a need to keep the models simple and, in agriculture studies, the focus of the analysis is often on the producer. However, our sample shows that the number of ABS models that incorporate multiple echelons is increasing (2001-2005: one paper, 2006-2010: three papers, 2011 onward: nine papers). This is a welcome trend as modelling multi-echelons should provide more insights for supply chain research (e.g., van der Vorst et al. (2000)).

Table 7 Summary of model details

\begin{tabular}{|l|l|r|}
\hline Classification & Category & Number of papers \\
\hline \multirow{4}{*}{ Agents in the model } & Producer & 55 \\
\cline { 2 - 3 } & Post-harvest & 5 \\
\cline { 2 - 3 } & Processor & 5 \\
\cline { 2 - 3 } & Retailer & 6 \\
\cline { 2 - 3 } & Consumer & 5 \\
\cline { 2 - 3 } & Other & 3 \\
\hline Number of ASC echelons & 1 & 44 \\
\cline { 2 - 3 } & 2 & 9 \\
\cline { 2 - 3 } & 3 & 2 \\
\cline { 2 - 3 } & 4 & 2 \\
\cline { 2 - 3 } & 5 & 1 \\
\hline \multirow{5}{*}{ Decision-making rule } & Rule-based & 46 \\
\cline { 2 - 3 } & Equation-based & 22 \\
\hline \multirow{5}{*}{ Type of interactions } & Narrowcast & 35 \\
\cline { 2 - 3 } & Broadcast & 20 \\
\hline \multirow{5}{*}{ of agent decisions } & Production planning & 34 \\
\cline { 2 - 3 } & Investment & 20 \\
\cline { 2 - 3 } & Technology choice and adoption & 11 \\
\cline { 2 - 3 } & Cooperation & 10 \\
\cline { 2 - 3 } & Product tracing or quality & 5 \\
\cline { 2 - 3 } & Selling & 5 \\
\cline { 2 - 3 } & Product delivery & 4 \\
\cline { 2 - 3 } & Other & 2 \\
\hline
\end{tabular}


Dhanan Sarwo Utomo, Bhakti Stephan Onggo, Stephen Eldridge, Applications of agent-based modelling and simulation in the agri-food supply chains, In European Journal of Operational Research, 2017, ISSN 0377-2217, https://doi.org/10.1016/j.ejor.2017.10.041.

We divide how decision-making rules are represented in an ABS model into two categories: equation-based and rule-based (both categories may be used in one model). The equation-based representations use mathematical equations such as: linear programming (e.g., Becu et al. (2003)); mixed integer programming (e.g., Berger (2001), Happe et al. (2006) and Schreinemachers and Berger (2011)); and regression modelling (e.g., Bakker et al. (2015)). The rule-based representation uses declarative languages such as "if then else" rules (e.g., Morgan and Daigneault (2015)), threshold models (e.g., Quang et al. (2014)) and imitation models (e.g., Osinga et al. (2015)).

The interactions among agents in an ABS model can be divided into narrowcast (i.e., an agent only interacts with its neighbours) or broadcast (i.e., an agent interacts with all or most of other agents) (Onggo et al., 2014). An example of narrowcast interaction is described in Zheng et al. (2015) in which agents gain knowledge regarding innovations from their neighbours. An example of broadcast interaction is presented in Quang et al. (2014) in which agents monitor the adoption rate in the population and compare it to their willingness to take risk when deciding to adopt an innovation.

In terms of types of decision, we proposed the following categories:

- Production planning: determining the type and quantity of commodities to be produced, land allocation and resource allocation. All these decisions are usually modelled together (e.g., Berger (2001), Happe et al. (2006) and Krejci and Beamon (2015)).

- Investment: deciding to buy or sell land, adding or selling machinery (e.g., Schreinemachers et al. (2009), Schouten et al. (2014)).

- Technology choice and adoption: deciding when and how to share knowledge with other agents and adopt a new innovation (e.g., Olabisi et al. (2015), Berger et al. (2006)).

- Cooperation: deciding when and how to cooperate with other agents (e.g., Krejci and Beamon (2015)) and selecting partners to cooperate (e.g., Gagliardi et al. (2014)).

- Product tracing or quality: deciding how to control product quality and how to trace a product's source (e.g., Ge et al. (2015a), Ge et al. (2015b))

- Selling: deciding where the agent will sell its products (e.g., Krejci et al. (2016))

- Product delivery: deciding, for example, whether the agent will send products according to the specifications agreed with the buyer or not (e.g., Tykhonov et al. (2008)).

- Others: decisions including managing irrigation in Becu et al. (2003) and pricing in Graubner et al. (2011)

Table 7 shows the dominance of production planning decisions and reflects the focus on just the producer as the only supply chain echelon ( 31 of 34 studies). Even so, understanding how farmers determine their production strategy and its consequences is important and interesting for researchers. 
Dhanan Sarwo Utomo, Bhakti Stephan Onggo, Stephen Eldridge, Applications of agent-based modelling and simulation in the agri-food supply chains, In European Journal of Operational Research, 2017, ISSN 0377-2217, https://doi.org/10.1016/j.ejor.2017.10.041.

\subsection{Validation and Sensitivity Analysis}

Macal (2016) observes that what ABS gains in its ability to model complexity is offset by losses in its analytical tractability which includes issues relating to experiment design, output analysis and validation using empirical data. Our literature review illustrates that this observation is particularly true for ABS applications in ASC. In this section, we discuss how ABS applications in ASC deal with validation and experimentation issues. In our discussion, we classify validation techniques into theoretical (i.e., comparing model behaviours with theory), and empirical validation (i.e., comparing model behaviours with observation or expert judgement).

It is also possible to classify the validation techniques of simulation models, including ABS models, into black box and white box validation (Montanola-Sales et al., 2011, Kleijnen, 1995)). Black box validation evaluates whether the model outputs either reflect the empirical observations for the same set of inputs (e.g., Malawska and Topping (2016), Berger (2001)) or are consistent with the result from a mathematical model (e.g., Onggo and Karatas (2016), Ge et al. (2015a)). White box validation evaluates whether the decision rules of agents represent the decision rules of actors in the real world and whether the structure of the model (such as the network between agents) represents reality. This includes techniques such as examining the validity of the model structure, i.e. static logic and the dynamic logic of the model components and behaviours (Montanola-Sales et al., 2011, Pidd, 2004) and interactive modelling sessions (Arnold et al., 2015, Berger and Troost, 2014).

Table 8 shows that the validation process used by 27 studies (i.e. $47 \%$ ) is unclear or unspecified. However, it is encouraging that the proportion of papers in this category may be declining (57\% between 2001 and 2006, 42\% between 2007 and 2012, and 47\% from 2013 onward). This finding is consistent with the earlier observations by Heath et al. (2009) that the number of ABS papers without validation continues to decrease every year. In our sample, $67 \%$ of studies using hypothetical cases and $40 \%$ of studies using real cases are not validated. In addition, many theory development studies are not accompanied by a validation process (52\%). However, fewer policy development and methodology development studies are without validation details ( $37 \%$ and $22 \%$, respectively).

Table 8 Paper classification based on the validation technique

\begin{tabular}{|l|l|l|c|}
\hline Validation information & Classification & Category & Number of papers \\
\hline Absent or unclear & N/A & N/A & 27 \\
\hline \multirow{3}{*}{ Present } & Based on data & Theoretical & 7 \\
\cline { 3 - 4 } & & Empirical & 25 \\
\cline { 2 - 4 } & \multirow{2}{*}{ Process } & Black box & 30 \\
\cline { 3 - 4 } & & White box & 2 \\
\hline
\end{tabular}

Empirical validation is the most popular means to validate ABS models in ASC. This method includes: visual comparison between the trends produced by simulation and the actual trends (e.g., Brändle et al. (2015)); statistical comparison (e.g., Malawska and Topping (2016)); and 
Dhanan Sarwo Utomo, Bhakti Stephan Onggo, Stephen Eldridge, Applications of agent-based modelling and simulation in the agri-food supply chains, In European Journal of Operational Research, 2017, ISSN 0377-2217, https://doi.org/10.1016/j.ejor.2017.10.041.

fitting a regression line between the simulated and actual data (e.g., Berger (2001), Schreinemachers et al. (2007), Schreinemachers et al. (2010) and Marohn et al. (2013)). Alternatively, theoretical validation is adopted frequently when validating difficult-to-measure qualitative behaviours (e.g., Tykhonov et al. (2008)). Reasons for this include the lack of widely available historical qualitative data or this data may not be in a form that can be readily used for simulation. Furthermore, standard statistical techniques may not be suitable for validating qualitative behaviour. Only two papers in our dataset employs white-box validation (i.e., Bert et al. (2014) and Arnold et al. (2015)) which is a concern, especially considering that black-box and white-box validations are complementary activities (Montanola-Sales et al., 2011).

To interpret the result of a simulation study, it is important to describe the statistical features of its outputs (Hamill, 2010). Furthermore, the shape of a simulation output distribution is usually a priori unknown and an appropriate number of replications is needed to produce meaningful statistics (Lee et al., 2015). Table 9 shows that 23 of 58 papers do not explicitly mention the number of replications used in the experiment or report the confidence interval of their simulation. The table also shows that a subjective method using researcher judgement is by far the most common with a range of 10 to 350 replications. The only exception is the study by Osinga et al. (2015) which uses an objective method based on the coefficient of variation (Lorscheid et al., 2012).

Sensitivity analysis can be used to understand the risk from making a decision based on a model because many input parameters are estimated and, for ABS models, the parameters are often estimated subjectively. Sensitivity analysis can also be used as a form of model validation by checking that the model reacts correctly to changes in input parameters (Sargent, 2013). In the context of $A B S$, sensitivity analysis can also be used to gain insight into the patterns and emergent properties of the model (ten Broeke et al., 2016). Sensitivity analysis techniques can be broadly categorised into one factor at a time (OFAT) and global sensitivity analysis (GSA). OFAT sensitivity analysis requires us to select a set of parameter values (baseline) and then vary one parameter at a time while keeping all other parameters fixed. Hence, OFAT does not take into account the possible interaction effects between parameters. On the other hand, GSA includes the interaction effects by sampling a model's outputs over a wide range of parameter values and then fitting a regression function or calculating sensitivity indices for these outputs (Sobol', 2001, ten Broeke et al., 2016). Table 9 shows that most of the studies use OFAT. It should be noted that the proportion of papers that do not apply sensitivity analysis is relatively high (28\%). However, our sample suggests that the proportion of studies reported without sensitivity analysis is decreasing (75\% between 2001 and 2005, 23\% between 2006 and 2010, 24\% from 2011 onward). Those without sensitivity analysis are mostly theoretical papers (63\%). Although ABS models used for theory development are not directly used for policy decision making, sensitivity analysis is still important to either ensure that the proposed theories are robust or find the parameter boundaries for which the proposed theories are valid. 
Dhanan Sarwo Utomo, Bhakti Stephan Onggo, Stephen Eldridge, Applications of agent-based modelling and simulation in the agri-food supply chains, In European Journal of Operational Research, 2017, ISSN 0377-2217, https://doi.org/10.1016/j.ejor.2017.10.041.

Table 9 Summary of output analysis

\begin{tabular}{|l|l|c|}
\hline \multicolumn{1}{|c|}{ Output analysis } & \multicolumn{1}{|c|}{ Category } & Number of papers \\
\hline \multirow{5}{*}{ Number of replications } & $\begin{array}{l}\text { Determined with subjective } \\
\text { method }\end{array}$ & 28 \\
\cline { 2 - 3 } & Determined with objective method & 1 \\
\cline { 2 - 3 } & $\begin{array}{l}\text { N/A but confidence intervals were } \\
\text { given }\end{array}$ & 6 \\
\cline { 2 - 3 } & N/A, confidence intervals not given & 23 \\
\hline Sensitivity analysis & OFAT & 38 \\
\cline { 2 - 3 } & GSA & 4 \\
\cline { 2 - 3 } & N/A & 16 \\
\hline
\end{tabular}

\subsection{Model representation methods}

A good model representation is important for the communication between stakeholders which affects the credibility of a model (Onggo, 2013). It is also important to ensure that the model can be duplicated and developed further by other researchers (Collins et al., 2015). Table 10 shows that most papers do not use any structured model representation techniques (i.e. they describe the model in unstructured text). Simple flowcharts, Overview Design and Details protocol (ODD) (Grimm et al. (2010) and Unified Modelling Language (UML) are the most popular in those papers that use a structured representation technique. In our sample, flowchart representation has been used for a long time and ODD has started to gain popularity since 2011. ODD representation is particularly popular for papers published in environmental science journals.

Table 10: Classification based on model representation techniques

\begin{tabular}{|l|c|}
\hline Scope of policy & Number of Paper (percentage) \\
\hline Flowchart & $13(22 \%)$ \\
\hline ODD & $11(19 \%)$ \\
\hline UML & $1(2 \%)$ \\
\hline N/A & $33(57 \%)$ \\
\hline
\end{tabular}

\section{Discussion}

In this section, we discuss the main findings from our review with findings from similar reviews and identify research areas in the ASC that have not taken the advantage of ABS even though $A B S$ has been shown to be useful in those areas in other application domains. 
Dhanan Sarwo Utomo, Bhakti Stephan Onggo, Stephen Eldridge, Applications of agent-based modelling and simulation in the agri-food supply chains, In European Journal of Operational Research, 2017, ISSN 0377-2217, https://doi.org/10.1016/j.ejor.2017.10.041.

\subsection{The state of research in ASC that uses ABS}

There have been a number of reviews on the application of ABS in related application domains such as land use (Robinson et al., 2007), environmental science (Kelly et al., 2013) and forest product supply chain (Vahid et al. (2016). Table 11 summarises and compares these related reviews. We include Oliveira et al. (2016) because it provides the latest review on supply chain simulation (which includes 34 ABS papers). Consistent with our observations, Oliveira et al. (2016) and Vahid et al. (2016) both note the increase in the numbers of papers that use ABS which demonstrates that that ABS has been accepted as one of the analytical tools in these domains.

Table 11 shows that both hypothetical and real case studies are used in the literature. The number of cases reported from low income countries is low. The objectives of the ABS models reported in these earlier reviews are for theory and policy development. This outcome contrasts with our observation that there have been a significant number of papers that seek to improve ABS modelling methodology. In terms of data, most papers that use ABS for policy development in these earlier reviews use empirical data and those for theory development (e.g., most papers in (Oliveira et al., 2016)) use hypothetical data. This is consistent with the finding from our review. It should be noted that in their review, Robinson et al. (2007) indicate that there are other empirical data collection techniques that could be used for ABS. For example, discrete choice experiment has been used in the forestry domain (e.g., Holm et al. (2016)). Another method is the use of a social experiment which can help researchers understand how humans behave and has a strong grounding in economic theories (e.g., Barreteau et al. (2001)). Qualitative data collection methods such as the monographic case study have also been used in natural resource management domain (Castella et al., 2005b)). Qualitative data collection methods are very important since they may provide a deeper understanding of how actors make decision for a given context (Robinson et al., 2007). Our findings also confirm those of previous literature reviews that illustrate that most models use easy-to-measure output data.

Our review differs from the previous literature reviews by considering the model designs used in ABS studies (e.g., number of echelons, type of agents, agent's decision rules, and types of interaction). We find that most ABS applications in ASC focus on one echelon (i.e., the producer) and the simulation of production planning and investment decisions. The agents in the models mostly incorporate rule-based decision-making and narrowcast interactions. Furthermore, our review is exceptional in that it considers how the experimentation and model validation have been conducted and demonstrates that there has been an increase in the number of studies that carry out validation and sensitivity analysis. Finally, in term of model representation, the most commonly used methods for model representation are the flow chart and ODD but our findings also show that the majority of articles do not use any method for model representation. Overall, when compared with these earlier reviews, our review provides a more detailed analysis of the characteristics of ABS model design (number of echelon, type of agent, agent's decision, model representation and interaction), validation and sensitivity analysis. In other words, our review is done from the perspective of an ABS modeller. 
Dhanan Sarwo Utomo, Bhakti Stephan Onggo, Stephen Eldridge, Applications of agent-based modelling and simulation in the agri-food supply chains, In European Journal of Operational Research, 2017, ISSN 0377-2217, https://doi.org/10.1016/j.ejor.2017.10.041.

Table 11 Summary of discussion from other literature review

\begin{tabular}{|c|c|c|c|c|}
\hline Category & $\begin{array}{c}\text { Robinson et al. } \\
\text { (2007) }\end{array}$ & $\begin{array}{l}\text { Kelly et al. } \\
\text { (2013) }\end{array}$ & $\begin{array}{c}\text { Vahid et al. } \\
\text { (2016) }\end{array}$ & $\begin{array}{c}\text { Oliveira et al. } \\
\qquad(2016)\end{array}$ \\
\hline Review Purpose & $\begin{array}{l}\text { To compare } \\
\text { strengths and } \\
\text { weaknesses of } \\
\text { five data } \\
\text { collection } \\
\text { methods for ABS }\end{array}$ & $\begin{array}{l}\text { To compare five } \\
\text { approaches to } \\
\text { model complex } \\
\text { trade-offs in land } \\
\text { use }\end{array}$ & $\begin{array}{l}\text { To identify } \\
\text { challenges in } \\
\text { forest } \\
\text { products supply } \\
\text { chain research }\end{array}$ & $\begin{array}{l}\text { To identify } \\
\text { developments } \\
\text { and } \\
\text { advancements } \\
\text { in supply chain } \\
\text { simulations }\end{array}$ \\
\hline Review Domain & Land use science & $\begin{array}{l}\text { Environmental } \\
\text { science }\end{array}$ & $\begin{array}{l}\text { Forest products } \\
\text { supply chain }\end{array}$ & Supply chain \\
\hline Review Scope & $\begin{array}{l}\text { Five ABS papers } \\
(2001-2006)\end{array}$ & $\begin{array}{l}\text { Various methods } \\
\text { including } 11 \text { ABS } \\
\text { papers published } \\
\text { between } 2006 \\
\text { and } 2012\end{array}$ & $\begin{array}{l}\text { Various methods } \\
\text { including five } \\
\text { ABS papers } \\
\text { published } \\
\text { between } 2007 \\
\text { and } 2012\end{array}$ & $\begin{array}{l}\text { Simulation } \\
\text { papers including } \\
34 \text { ABS papers } \\
\text { published } \\
\text { between } 1992 \\
\text { and } 2014\end{array}$ \\
\hline $\begin{array}{l}\text { Research } \\
\text { Context }\end{array}$ & $\begin{array}{l}\text { Five real cases } \\
\text { from one low- } \\
\text { income, three } \\
\text { middle-income } \\
\text { and one high- } \\
\text { income } \\
\text { countries }\end{array}$ & $\begin{array}{l}\text { Four } \\
\text { hypothetical } \\
\text { models; one low- } \\
\text { income, two } \\
\text { middle-income, } \\
\text { and four high- } \\
\text { income countries }\end{array}$ & $\begin{array}{l}\text { Real cases from } \\
\text { high income } \\
\text { countries }\end{array}$ & $\begin{array}{l}\text { From all papers } \\
\text { (including ABS), } \\
57 \% \text { use } \\
\text { hypothetical } \\
\text { case and } 43 \% \\
\text { use real case }\end{array}$ \\
\hline $\begin{array}{l}\text { ABS Research } \\
\text { Objective }\end{array}$ & $\begin{array}{l}\text { Mainly for policy } \\
\text { development }\end{array}$ & $\begin{array}{l}\text { Theory \& policy } \\
\text { development }\end{array}$ & Not discussed & $\begin{array}{l}\text { Mainly theory } \\
\text { development }\end{array}$ \\
\hline $\begin{array}{l}\text { Data collection } \\
\text { method }\end{array}$ & $\begin{array}{l}\text { Qualitative \& } \\
\text { quantitative } \\
\text { data collection } \\
\text { methods }\end{array}$ & Not discussed & Not discussed & $\begin{array}{c}42 \% \text { use } \\
\text { empirical data } \\
\text { (the method } \\
\text { was not } \\
\text { discussed) }\end{array}$ \\
\hline $\begin{array}{l}\text { Output data } \\
\text { analysis }\end{array}$ & Not discussed & $\begin{array}{c}\text { Mainly easy-to- } \\
\text { measure }\end{array}$ & Easy-to-measure & Not discussed \\
\hline Model design & Not discussed & Not discussed & Not discussed & Not discussed \\
\hline $\begin{array}{l}\text { Validation \& } \\
\text { Sensitivity } \\
\text { Analysis }\end{array}$ & Not discussed & Not discussed & Not discussed & Not discussed \\
\hline $\begin{array}{l}\text { Model } \\
\text { Representation }\end{array}$ & Not discussed & Not discussed & Mainly ODD & Not discussed \\
\hline
\end{tabular}


Dhanan Sarwo Utomo, Bhakti Stephan Onggo, Stephen Eldridge, Applications of agent-based modelling and simulation in the agri-food supply chains, In European Journal of Operational Research, 2017, ISSN 0377-2217, https://doi.org/10.1016/j.ejor.2017.10.041.

\subsection{The gap between ASC and ABS research topic}

In this section, we highlight those topics within ASC in which ABS has not yet been used even though ABS may have been used to address similar topics in other supply chain domains. To achieve this, VOSviewer software (van Eck and Waltman, 2009) was used to create a cooccurrence network of the terms obtained from the titles, abstract and keywords in dataset D1. Two terms are said to co-occur if they both occur on the same line. Terms with similar meaning were grouped together using the VOSviewer thesaurus (e.g., "agent-based" and "ABM"). VOSviewer places the terms in the network in such a way that the distance between two terms indicates the number of co-occurrences of those terms. Based on this network, VOSviewer identifies a number of clusters. Figure 3 shows the co-occurrence network of the terms used in ASC literature and the clusters identified (each colour represents one cluster and we have also added the circles to make the cluster more visible).

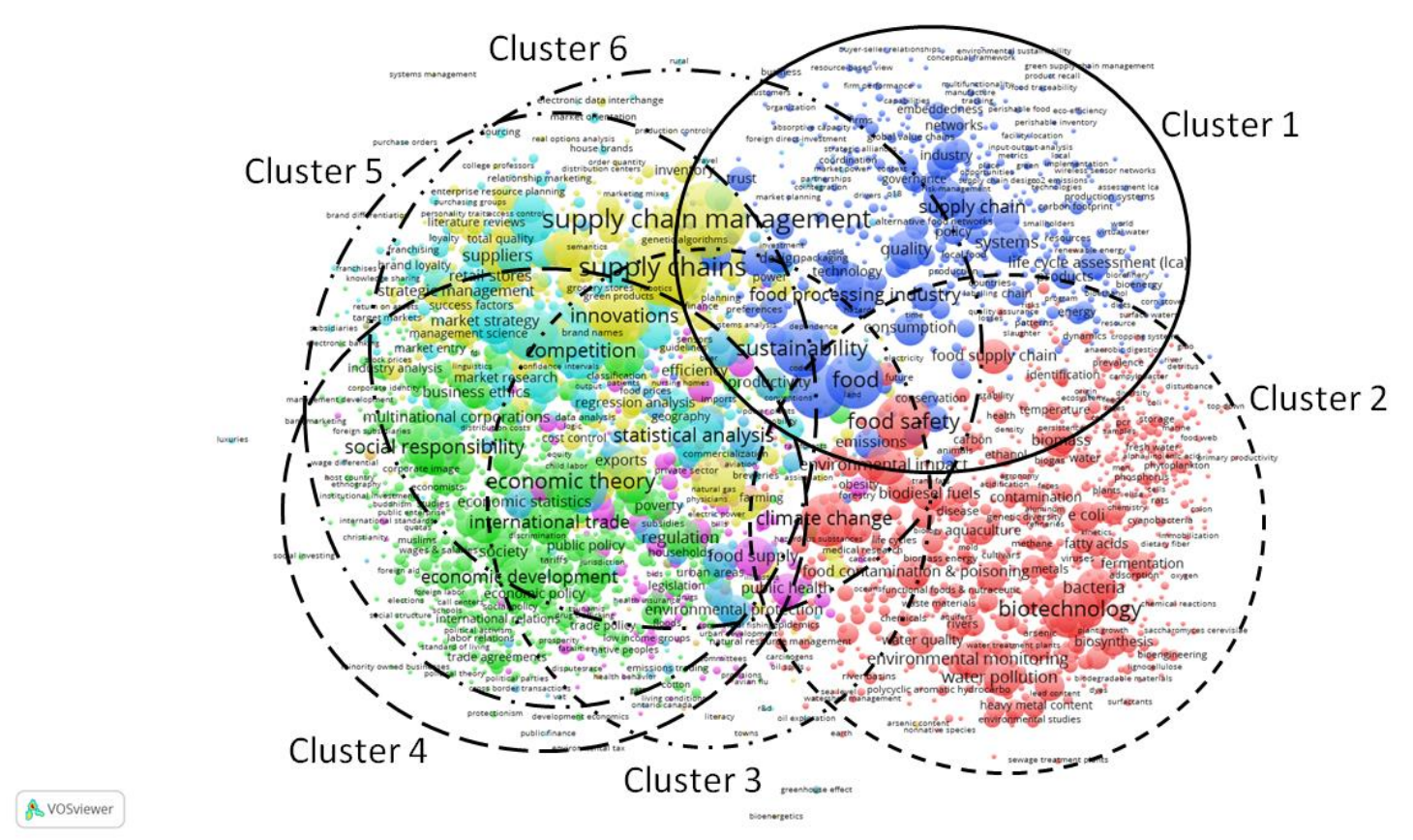

Figure 3 Bibliographic mapping of ASC research

To understand what these six research clusters represent, we identified the most popular keywords in each cluster and these are listed in Table 12. Based on these keywords, these clusters represent ASC-related research from: logistics, supply chain and management science (cluster 1); natural sciences such as biotechnology, microbiology and environmental science (cluster 2); humanitarian aid and public health (cluster 3); political economics (cluster 4); marketing (cluster 5); and general management (cluster 6).

Table 12 Top 10 popular keywords in each cluster of ASC research

Cluster 1

Cluster 2

Cluster 3

Cluster 4

Cluster 5

Cluster 6 
Dhanan Sarwo Utomo, Bhakti Stephan Onggo, Stephen Eldridge, Applications of agent-based modelling and simulation in the agri-food supply chains, In European Journal of Operational Research, 2017, ISSN 0377-2217, https://doi.org/10.1016/j.ejor.2017.10.041.

\begin{tabular}{|l|l|l|l|l|l|}
\hline $\begin{array}{l}\text { supply chain } \\
\text { management }\end{array}$ & biotechnology & food supply & $\begin{array}{l}\text { economic } \\
\text { theory }\end{array}$ & Competition & sustainability \\
\hline supply chains & food safety & public health & $\begin{array}{l}\text { social } \\
\text { responsibility }\end{array}$ & Marketing & food \\
\hline Innovations & climate change & Certification & $\begin{array}{l}\text { economic } \\
\text { development }\end{array}$ & $\begin{array}{l}\text { statistical } \\
\text { analysis }\end{array}$ & agriculture \\
\hline Logistics & $\begin{array}{l}\text { environmental } \\
\text { impact }\end{array}$ & $\begin{array}{l}\text { risk } \\
\text { management }\end{array}$ & $\begin{array}{l}\text { international } \\
\text { trade }\end{array}$ & SME & food processor \\
\hline $\begin{array}{l}\text { sustainable } \\
\text { development }\end{array}$ & bacteria & $\begin{array}{l}\text { pharmaceutical } \\
\text { industry }\end{array}$ & globalization & $\begin{array}{l}\text { competitive } \\
\text { advantage }\end{array}$ & management \\
\hline $\begin{array}{l}\text { decision } \\
\text { making }\end{array}$ & $\begin{array}{l}\text { environmental } \\
\text { monitoring }\end{array}$ & Disasters & regulation & $\begin{array}{l}\text { consumer } \\
\text { behaviour }\end{array}$ & value chain \\
\hline $\begin{array}{l}\text { operations } \\
\text { research }\end{array}$ & $\begin{array}{l}\text { food supply } \\
\text { chain }\end{array}$ & $\begin{array}{l}\text { humanitarian } \\
\text { aid }\end{array}$ & $\begin{array}{l}\text { impact } \\
\text { analysis }\end{array}$ & CSR & collaboration \\
\hline $\begin{array}{l}\text { buyer-seller } \\
\text { food } \\
\text { contamination } \\
\text { \& poisoning }\end{array}$ & obesity & $\begin{array}{l}\text { business } \\
\text { ethics }\end{array}$ & retailing & supermarkets \\
\hline $\begin{array}{l}\text { information } \\
\text { systems }\end{array}$ & microbiology & $\begin{array}{l}\text { emergency } \\
\text { preparedness }\end{array}$ & Cooperation & $\begin{array}{l}\text { market } \\
\text { strategy }\end{array}$ & $\begin{array}{l}\text { transaction } \\
\text { cost } \\
\text { economics }\end{array}$ \\
\hline $\begin{array}{l}\text { management } \\
\text { science }\end{array}$ & e-coli & $\begin{array}{l}\text { nutrition } \\
\text { research }\end{array}$ & $\begin{array}{l}\text { politics } \\
\text { based view }\end{array}$ \\
\hline
\end{tabular}

Figure 4 shows the co-occurrence network of the terms used in the use of ABS in the ASC literature (i.e., dataset D2) and five research clusters were identified (each colour represents one cluster and we have also added the circles to make the cluster more visible). Cluster 1 represents papers focusing on understanding the agricultural system, including land use and crop production. Cluster 2 consists of papers aiming at modelling climate change adaptation, proposing mitigation policies and assessing their impact. Cluster 3 is the group of methodological papers including sensitivity analysis and parameter uncertainty handling. Research in cluster 4 focuses on modelling the complexity in food supply chains including interaction with the environment, social network and heterogeneity. Cluster 5 includes those studies modelling the diffusion of innovation. 
Dhanan Sarwo Utomo, Bhakti Stephan Onggo, Stephen Eldridge, Applications of agent-based modelling and simulation in the agri-food supply chains, In European Journal of Operational Research, 2017, ISSN 0377-2217, https://doi.org/10.1016/j.ejor.2017.10.041.

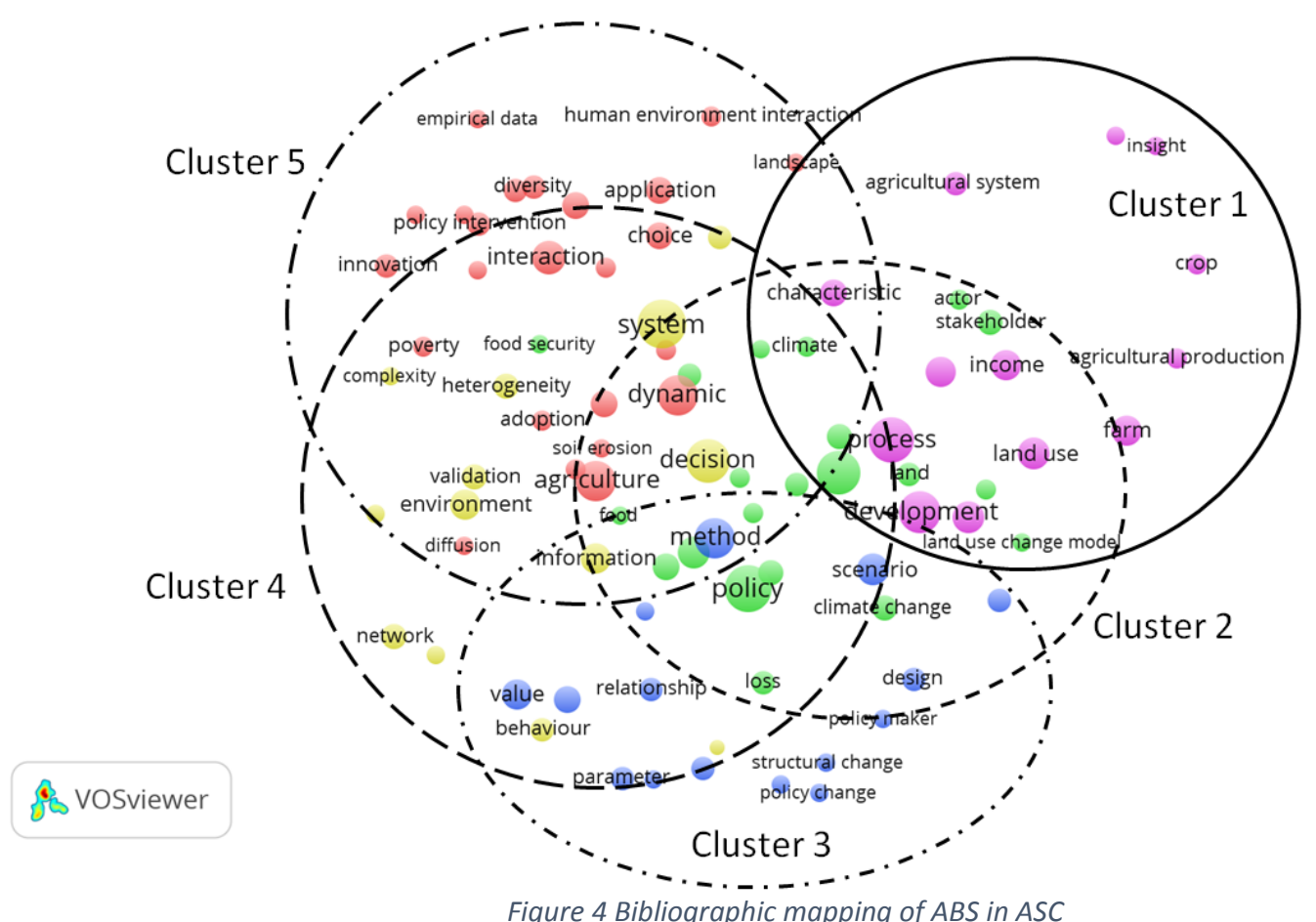

Table 13 Top 10 popular keywords in each cluster of ABS research

\begin{tabular}{|l|l|l|l|l|}
\hline \multicolumn{1}{|c|}{$\begin{array}{c}\text { Cluster } \mathbf{1} \\
\text { (18 papers) }\end{array}$} & \multicolumn{1}{|c|}{$\begin{array}{c}\text { Cluster } \mathbf{2} \\
\text { (20 papers) }\end{array}$} & \multicolumn{1}{c|}{$\begin{array}{c}\text { Cluster } \mathbf{3} \\
\mathbf{( 1 5} \text { papers) }\end{array}$} & \multicolumn{1}{c|}{$\begin{array}{c}\text { Cluster } \mathbf{4} \\
\text { (22 papers) }\end{array}$} & \multicolumn{1}{c|}{$\begin{array}{c}\text { Cluster } \mathbf{5} \\
\text { (15 papers) }\end{array}$} \\
\hline process & policy & method & system & Dynamic \\
\hline development & $\begin{array}{l}\text { farmer decision } \\
\text { making }\end{array}$ & scenario & decision & agriculture \\
\hline land use & market & Value & Information & interaction \\
\hline structure & price & Uncertainty & environment & Choice \\
\hline farm & role & Relationship & Social network & Resource \\
\hline income & stakeholder & Design & heterogeneity & farm household \\
\hline production & assessment & management & complexity & application \\
\hline characteristic & climate change & Parameter & comparison & innovation \\
\hline agricultural system & adaptation & sensitivity analysis & behaviour & policy intervention \\
\hline crop & Individual & policy change & food supply chain & diffusion \\
\hline
\end{tabular}

In this section, clusters and popular keywords in ASC research and in ABS research have been presented. By comparing the keywords presented in Table 12 and Table 13, we can identify areas in ASC research (dataset D1) that are under-represented or missing in ASC research that uses ABS (dataset D2). These gaps may arise because ABS is not the right tool to research into these areas. However, further consideration of these areas and the benefit from the application of $A B S$ is warranted. Based upon our review, we suggest the following research opportunities: 
Dhanan Sarwo Utomo, Bhakti Stephan Onggo, Stephen Eldridge, Applications of agent-based modelling and simulation in the agri-food supply chains, In European Journal of Operational Research, 2017, ISSN 0377-2217, https://doi.org/10.1016/j.ejor.2017.10.041.

- Cooperation, competition and collaboration: These keywords appear in clusters 4, 5 and 6 in Table 12 but are missing from Table 13. ABS has been used to study cooperation, competition and collaboration in other domains. For example, in innovative product supply chains, Arvitrida et al. (2015) used ABS to explain the effect of competition and collaboration on supply chain performance (supply chain's survival and profit). He et al. (2013) provide an example of an ABS application in a retail supply chain. Specifically, they study the optimal strategy to respond to competition in the retail industry and find that everyday-low-price strategy is the best. From data set D2, we can only find two papers studies the collaboration between ASC actors (Krejci and Beamon (2015) and Boero (2011)). One main advantage of $A B S$ is its ability to model the interactions between actors in a social network. Hence, ABS should play more important role in the research into cooperation, competition and collaboration in ASC. For example, we could use ABS to study the effect of the collaboration strategy between farmers and supermarkets on supply chain survivals.

- Buyer-seller relationship: The keyword buyer-seller appears in cluster 1 in Table 12 but missing from Table 13. This keyword is a result of thesaurus grouping, and includes sub-keywords such as supplier, supplier relationship and buyer-seller in ASC research which are important concepts (e.g., Emanuela (2012)). ABS has already been used to study buyer-seller relationships in ASC (i.e., Tykhonov et al. (2008). This is the only example from dataset D2. ABS was used to simulate how different levels of trust and honesty affect the interactions between buyers and sellers in ASC. We know that ABS has been used to study buyer-seller relationship in the supply chain literature. For example, ABS has been used to study the general partner selection problem in a supply chain (e.g., Schieritz and Grobler (2003). In another context, Franke et al. (2005) use ABS to demonstrate how buyer's trust and seller's reputation can lead to more stable supply chain and in some cases, monopoly to arise. Hence, we believe that $A B S$ has potential for research into different aspects of buyer-seller relationship in ASC. For example, we can use ABS to study the impact of strength of buyerseller relationship (e.g., level of loyalty) on the average market price and production volume of an agri-food product.

- Service: This keyword is a result of thesaurus grouping, and includes sub-keywords such as customer service, food service, service industries and service architecture. The keyword service appears in cluster 5 of Table 12 but is missing from Table 13. ABS is one of the methods that is suitable for research into services in supply chains (Lusch, 2011). For example Rouzafzoon and Helo (2016) use ABS to study the service distribution and location problem in a healthcare supply chain. We believe that ABS is also relevant to researching services in ASC. For example, we can use ABS to study the effect of locations of service providers (e.g. post-harvesting, handling, bottling and packaging) and the level of service provision on ASC performance.

In addition to the research areas highlighted above, we also found that food processors, supermarkets and retailers have not yet widely considered in ASC research that uses ABS. This is illustrated by keywords related to food processor, supermarket and retail being used frequently in ASC research (Table 12) and indicates the importance of these actors in ASC. However, these 
Dhanan Sarwo Utomo, Bhakti Stephan Onggo, Stephen Eldridge, Applications of agent-based modelling and simulation in the agri-food supply chains, In European Journal of Operational Research, 2017, ISSN 0377-2217, https://doi.org/10.1016/j.ejor.2017.10.041.

keywords are missing from Table 13. This may be due to the commercial confidentiality of the data related to these ASC actors. Publicly available retail data sources include the IRI Marketing Data Set (Bronnenberg et al., 2008) and initiatives such as Consumer Data Research Centre (CDRC, 2017) may be useful in providing to access individual data. As for the aggregated data, methods such as that proposed by Troost and Berger (2015) are needed to calibrate an ABS model. Another technique that can be used is to ask these agents only to disclose reasonable assumptions regarding confidential information and parameters. The researchers then can perform sensitivity analysis on these parameters and check whether the corresponding variances are still within acceptable boundaries (see, for example, Sonderegger-Wakolbinger and Stummer (2015) in luxury goods context).

We also observed that ASC research frequently uses Transaction Cost Economics and/or the Resource-Based View to provide its theoretical foundation. These keywords are also missing from Table 13 which indicates that they have not yet been used in the ABS models for ASC despite there being a number of examples that illustrate how these theories can be incorporated, in ABS in general (e.g., Klos and Nooteboom (2001), Bylund (2015)).

\section{Conclusions}

We have presented a literature review of research in Agri-food supply chain (ASC) that uses agent-based simulation (ABS) as the main modelling tool. Our findings demonstrate that the number of papers addressing ASC policies has increased which suggests that researchers have started to apply ABS for real world decision-making related to ASC. Similarly, there has been an increase in the number of papers addressing the methodological aspect of ABS for ASC research, which indicates that ABS has gained acceptance as a modelling tool in this application domain. The increase in the number of papers with model validation is another positive development.

ABS research in this area has been dominated by the following characteristics: single echelon supply chains; cases in high and middle income countries; unprocessed food products; use of empirical data (especially from secondary sources, surveys and interviews); decisions related to production planning and investment; and the use of black box validation (especially in combination with empirical data). In comparison to earlier reviews of the use of ABS in other related domains, this review encompasses more papers and, more importantly, it provides a comprehensive review of ABS model design and ABS modelling approaches in ASC research.

We have also demonstrated how the bibliographic mapping technique can be used to highlight potential research areas within ASC that have not yet taken advantage of ABS despite ABS being shown to be valuable in similar research areas in other application domains. The identified research areas are: cooperation and competition; buyer-seller relationships; and service in supply chains. We have highlighted that some important actors in ASC, such as food processors and supermarkets, are rarely modelled using ABS. Furthermore, general theoretical frameworks such as Transaction Cost Economics and the Resource-Based View could potentially be incorporated into the design of these models. 
Dhanan Sarwo Utomo, Bhakti Stephan Onggo, Stephen Eldridge, Applications of agent-based modelling and simulation in the agri-food supply chains, In European Journal of Operational Research, 2017, ISSN 0377-2217, https://doi.org/10.1016/j.ejor.2017.10.041.

\section{Acknowledgements}

We would like to thank the anonymous reviewers for their constructive and detailed suggestions on this paper.

\section{References}

AHUMADA, O. \& VILLALOBOS, J. R. 2009. Application of planning models in the agri-food supply chain: A review. European Journal of Operational Research, 196, 1-20.

ALBINO, V., FRACCASCIA, L. \& GIANNOCCARO, I. 2016. Exploring the role of contracts to support the emergence of self-organized industrial symbiosis networks: an agent-based simulation study. Journal of Cleaner Production, 112, Part 5, 4353-4366.

ARNOLD, R., TROOST, C. \& BERGER, T. 2015. Quantifying the economic importance of irrigation water reuse in a Chilean watershed using an integrated agent-based model. Water Resources Research, 51, 648-668.

ARVITRIDA, N. I., ROBINSON, S. \& TAKO, A. A. How do competition and collaboration affect supply chain performance? An agent based modeling approach. Winter Simulation Conference (WSC), 2015, 2015. IEEE, 218-229.

AURBACHER, J., PARKER, P. S., CALBERTO SÁNCHEZ, G. A., STEINBACH, J., REINMUTH, E., INGWERSEN, J. \& DABBERT, S. 2013. Influence of climate change on short term management of field crops - A modelling approach. Agricultural Systems, 119, 44-57.

BAKKER, M. M., ALAM, S. J., VAN DIJK, J. \& ROUNSEVELL, M. D. A. 2015. Land-use change arising from rural land exchange: an agent-based simulation model. Landscape Ecology, 30, 273286.

BARRETEAU, O., BOUSQUET, F. \& ATTONATY, J. M. 2001. Role-playing games for opening the black box of multi-agent systems. Journal of Artificial Societies and Social Simulation, 4.

BARRETT, C. B., BACHKE, M. E., BELLEMARE, M. F., MICHELSON, H. C., NARAYANAN, S. \& WALKER, T. F. 2012. Smallholder Participation in Contract Farming: Comparative Evidence from Five Countries. World Development, 40, 715-730.

BECU, N., PEREZ, P., WALKER, A., BARRETEAU, O. \& PAGE, C. L. 2003. Agent based simulation of a small catchment water management in northern Thailand: Description of the CATCHSCAPE model. Ecological Modelling, 170, 319-331.

BERGER, T. 2001. Agent-based spatial models applied to agriculture: a simulation tool for technology diffusion, resource use changes and policy analysis. Agricultural Economics, 25, 245-260.

BERGER, T. \& SCHREINEMACHERS, P. 2006. Creating agents and landscapes for multiagent systems from random samples. Ecology and Society, 11, 19.

BERGER, T., SCHREINEMACHERS, P. \& WOELCKE, J. 2006. Multi-agent simulation for the targeting of development policies in less-favored areas. Agricultural Systems, 88, 28-43.

BERGER, T. \& TROOST, C. 2014. Agent-based Modelling of Climate Adaptation and Mitigation Options in Agriculture. Journal of Agricultural Economics, 65, 323-348.

BERT, F. E., PODESTÁ, G. P., ROVERE, S. L., MENÉNDEZ, Á. N., NORTH, M., TATARA, E., LACIANA, C. E., WEBER, E. \& TORANZO, F. R. 2011. An agent based model to simulate structural and 
Dhanan Sarwo Utomo, Bhakti Stephan Onggo, Stephen Eldridge, Applications of agent-based modelling and simulation in the agri-food supply chains, In European Journal of Operational Research, 2017, ISSN 0377-2217, https://doi.org/10.1016/j.ejor.2017.10.041.

land use changes in agricultural systems of the argentine pampas. Ecological Modelling, 222, 3486-3499.

BERT, F. E., ROVERE, S. L., MACAL, C. M., NORTH, M. J. \& PODESTÁ, G. P. 2014. Lessons from a comprehensive validation of an agent based-model: The experience of the Pampas Model of Argentinean agricultural systems. Ecological Modelling, 273, 284-298.

BHARWANI, S., BITHELL, M., DOWNING, T. E., NEW, M., WASHINGTON, R. \& ZIERVOGEL, G. 2005. Multi-Agent Modelling of Climate Outlooks and Food Security on a Community Garden Scheme in Limpopo, South Africa. Philosophical Transactions: Biological Sciences, 360, 2183-2194.

BOERO, R. 2011. Food quality as a public good: cooperation dynamics and economic development in a rural community. Mind \& Society, 10, 203-215.

BORODIN, V., BOURTEMBOURG, J., HNAIEN, F. \& LABADIE, N. 2016. Handling uncertainty in agricultural supply chain management: A state of the art. European Journal of Operational Research, 254, 348-359.

BOYER, C. N. \& BRORSEN, B. W. 2013. Changes in Beef Packers' Market Power after the Livestock Mandatory Price Reporting Act: An Agent-based Auction. American Journal of Agricultural Economics, 95, 859-876.

BRÄNDLE, M. J., LANGENDIJK, G., PETER, S., BRUNNER, H. S. \& HUBER, R. 2015. Sensitivity Analysis of a Land-Use Change Model with and without Agents to Assess Land Abandonment and Long-Term Re-Forestation in a Swiss Mountain Region. Land, 4.

BRONNENBERG, B. J., KRUGER, M. W. \& MELA, C. F. 2008. Database paper-The IRI marketing data set. Marketing science, 27, 745-748.

BUSBY, J. S., ONGGO, B. S. S. \& LIU, Y. 2016. Agent-based computational modelling of social risk responses. European Journal of Operational Research, 251, 1029-1042.

BUSBY, S. J. \& ONGGO, S. 2013. Managing the social amplification of risk: a simulation of interacting actors. Journal of the Operational Research Society, 64, 638-653.

BYLUND, P. L. 2015. Signifying Williamson's Contribution to the Transaction Cost Approach: An Agent-Based Simulation of Coasean Transaction Costs and Specialization. Journal of Management Studies, 52, 148-174.

CASTELLA, J.-C., BOISSAU, S., TRUNG, T. N. \& QUANG, D. D. 2005a. Agrarian transition and lowland-upland interactions in mountain areas in northern Vietnam: application of a multi-agent simulation model. Agricultural Systems, 86, 312-332.

CASTELLA, J.-C., TRUNG, T. N. \& BOISSAU, S. 2005b. Participatory simulation of land-use changes in the northern mountains of Vietnam: the combined use of an agent-based model, a roleplaying game, and a geographic information system. Ecology and Society, 10, 27.

CDRC. 2017. Available: https://www.cdrc.ac.uk/ [Accessed 7 July 2017].

CHATURVEDI, A., ARMStRong, B. \& CHATURVEDI, R. 2014. Securing the food supply chain: understanding complex interdependence through agent-based simulation. Health and Technology, 4, 159-169.

CHEBOLU-SUBRAMANIAN, V. \& GAUKLER, G. M. 2015. Product contamination in a multi-stage food supply chain. European Journal of Operational Research, 244, 164-175. 
Dhanan Sarwo Utomo, Bhakti Stephan Onggo, Stephen Eldridge, Applications of agent-based modelling and simulation in the agri-food supply chains, In European Journal of Operational Research, 2017, ISSN 0377-2217, https://doi.org/10.1016/j.ejor.2017.10.041.

COLLINS, A., PETTY, M., VERNON-BIDO, D. \& SHERFEY, S. 2015. A Call to Arms: Standards for Agent-Based Modeling and Simulation. Journal of Artificial Societies and Social Simulation, $18,12$.

CUNNINGHAM, D. C. 2001. The distribution and extent of agrifood chain management research in the public domain. Supply Chain Management: An International Journal, 6, 212-215.

DA SILVA, C. A. \& DE SOUZA FILHO, H. M. 2007. Guidelines for rapid appraisals of agrifood chain performance in developing countries, Food and Agriculture Organization of the United Nations Rome.

EMANUELA, D. 2012. Outcomes of inter-organizational trust in supply chain relationships: a systematic literature review and a meta-analysis of the empirical evidence. Supply Chain Management: An International Journal, 17, 377-402.

FØLGESVOLD, A. \& PRENKERT, F. 2009. Magic pelagic - An agent-based simulation of 20 years of emergent value accumulation in the North Atlantic herring exchange system. Industrial Marketing Management, 38, 529-540.

FRANKE, J., STOCKHEIM, T. \& KÖNIG, W. 2005. The impact of reputation on supply chains. An analysis of permanent and discounted reputation. Information Systems and E-Business Management, 3, 323-341.

GAGLIARDI, D., NIGLIA, F. \& BATTISTELLA, C. 2014. Evaluation and design of innovation policies in the agro-food sector: An application of multilevel self-regulating agents. Technological Forecasting and Social Change, 85, 40-57.

GE, H., GRAY, R. \& NOLAN, J. 2015a. Agricultural supply chain optimization and complexity: A comparison of analytic vs simulated solutions and policies. International Journal of Production Economics, 159, 208-220.

GE, H., NOLAN, J. \& GRAY, R. 2015b. Identifying Strategies to Mitigate Handling Risks in the Canadian Grain Supply Chain. Canadian Journal of Agricultural Economics/Revue canadienne d'agroeconomie, 63, 101-128.

GODFRAY, H. C. J., BEDDINGTON, J. R., CRUTE, I. R., HADDAD, L., LAWRENCE, D., MUIR, J. F., PRETTY, J., ROBINSON, S., THOMAS, S. M. \& TOULMIN, C. 2010. Food Security: The Challenge of Feeding 9 Billion People. Science, 327, 812.

GRAUBNER, M., BALMANN, A. \& SEXTON, R. J. 2011. Spatial Price Discrimination in Agricultural Product Procurement Markets: A Computational Economics Approach. American Journal of Agricultural Economics, 93, 949-967.

HAMILL, L. 2010. Agent-based modelling: The next 15 years. Journal of Artificial Societies and Social Simulation, 13, 7.

HAPPE, K., HUTCHINGS, N. J., DALGAARD, T. \& KELLERMAN, K. 2011. Modelling the interactions between regional farming structure, nitrogen losses and environmental regulation. Agricultural Systems, 104, 281-291.

HAPPE, K., KELLERMANN, K. \& BALMANN, A. 2006. Agent-based Analysis of Agricultural Policies: an Illustration of the Agricultural Policy Simulator AgriPoliS, its Adaptation and Behavior. Ecology and Society, 11, 49. 
Dhanan Sarwo Utomo, Bhakti Stephan Onggo, Stephen Eldridge, Applications of agent-based modelling and simulation in the agri-food supply chains, In European Journal of Operational Research, 2017, ISSN 0377-2217, https://doi.org/10.1016/j.ejor.2017.10.041.

HE, Z., WANG, S. \& CHENG, T. C. E. 2013. Competition and evolution in multi-product supply chains: An agent-based retailer model. International Journal of Production Economics, 146, 325-336.

HEATH, B., HILL, R. \& CIARALLO, F. 2009. A survey of agent-based modeling practices (January 1998 to July 2008). Journal of Artificial Societies and Social Simulation, 12, 9.

HIGGINS, A., THORBURN, P., ARCHER, A. \& JAKKU, E. 2007. Opportunities for value chain research in sugar industries. Agricultural Systems, 94, 611-621.

HIGGINS, A. J., MILLER, C. J., ARCHER, A. A., TON, T., FLETCHER, C. S. \& MCALLISTER, R. R. J. 2010. Challenges of operations research practice in agricultural value chains. Journal of the Operational Research Society, 61, 964-973.

HOLM, S., LEMM, R., THEES, O. \& HILTY, L. M. 2016. Enhancing Agent-Based Models with Discrete Choice Experiments. Journal of Artificial Societies and Social Simulation, 19.

JANSSEN, S. \& VAN ITTERSUM, M. K. 2007. Assessing farm innovations and responses to policies: A review of bio-economic farm models. Agricultural Systems, 94, 622-636.

JULKA, N., SRINIVASAN, R. \& KARIMI, I. 2002. Agent-based supply chain management-1: framework. Computers \& Chemical Engineering, 26, 1755-1769.

KAUFMANN, P., STAGL, S. \& FRANKS, D. W. 2009. Simulating the diffusion of organic farming practices in two New EU Member States. Ecological Economics, 68, 2580-2593.

KAYE-BLAKE, B., SCHILLING, C. \& POST, E. 2014. Validation of an Agricultural MAS for Southland, New Zealand. Journal of Artificial Societies and Social Simulation, 17, 5.

KELLY, R. A., JAKEMAN, A. J., BARRETEAU, O., BORSUK, M. E., ELSAWAH, S., HAMILTON, S. H., HENRIKSEN, H. J., KUIKKA, S., MAIER, H. R., RIZZOLI, A. E., VAN DELDEN, H. \& VOINOV, A. A. 2013. Selecting among five common modelling approaches for integrated environmental assessment and management. Environmental Modelling \& Software, 47, 159-181.

KLEIJNEN, J. P. C. 1995. Verification and validation of simulation models. European journal of operational research, 82, 145-162.

KLOS, T. B. \& NOOTEBOOM, B. 2001. Agent-based computational transaction cost economics. Journal of Economic Dynamics and Control, 25, 503-526.

KREJCI, C. \& BEAMON, B. 2015. Impacts of Farmer Coordination Decisions on Food Supply Chain Structure. Journal of Artificial Societies and Social Simulation, 18, 19.

$\mathrm{KREJCl}, \mathrm{C}$. C. \& BEAMON, B. M. Modeling food supply chains using multi-agent simulation. Simulation Conference (WSC), Proceedings of the 2012 Winter, 9-12 Dec. 2012 2012. 112.

KREJCl, C. C., STONE, R. T., DORNEICH, M. C. \& GILBERT, S. B. 2016. Analysis of Food Hub Commerce and Participation Using Agent-Based Modeling: Integrating Financial and Social Drivers. Human Factors: The Journal of the Human Factors and Ergonomics Society, 58, 58-79.

KUTCHER, G. P. \& NORTON, R. D. 1982. Operations research methods in agricultural policy analysis. European Journal of Operational Research, 10, 333-345.

LEE, J.-S., FILATOVA, T., LIGMANN-ZIELINSKA, A., HASSANI-MAHMOOEI, B., STONEDAHL, F., LORSCHEID, I., VOINOV, A., POLHILL, G. J., SUN, Z. \& PARKER, D. C. 2015. The Complexities 
Dhanan Sarwo Utomo, Bhakti Stephan Onggo, Stephen Eldridge, Applications of agent-based modelling and simulation in the agri-food supply chains, In European Journal of Operational Research, 2017, ISSN 0377-2217, https://doi.org/10.1016/j.ejor.2017.10.041.

of Agent-Based Modeling Output Analysis. Journal of Artificial Societies and Social Simulation, 18, 4.

LORSCHEID, I., HEINE, B.-O. \& MEYER, M. 2012. Opening the 'black box' of simulations: increased transparency and effective communication through the systematic design of experiments. Computational and Mathematical Organization Theory, 18, 22-62.

LUSCH, R. F. 2011. Reframing supply chain management: a service-dominant logic perspective. Journal of Supply Chain Management, 47, 14-18.

MACAL, C. M. 2016. Everything you need to know about agent-based modelling and simulation. Journal of Simulation, 10, 144-156.

MALAWSKA, A. \& TOPPING, C. J. 2016. Evaluating the role of behavioral factors and practical constraints in the performance of an agent-based model of farmer decision making. Agricultural Systems, 143, 136-146.

MAROHN, C., SCHREINEMACHERS, P., QUANG, D. V., BERGER, T., SIRIPALANGKANONT, P., NGUYEN, T. T. \& CADISCH, G. 2013. A software coupling approach to assess low-cost soil conservation strategies for highland agriculture in Vietnam. Environmental Modelling \& Software, 45, 116-128.

MATTHEWS, R. B., GILBERT, N. G., ROACH, A., POLHILL, J. G. \& GOTTS, N. M. 2007. Agent-based land-use models: a review of applications. Landscape Ecology, 22, 1447-1459.

MCPHEE-KNOWLES, S. 2015. Growing Food Safety from the Bottom Up: An Agent-Based Model of Food Safety Inspections. Journal of Artificial Societies and Social Simulation, 18, 9.

MEIJER, S., HOFSTEDE, G. J., BEERS, G. \& OMTA, S. W. F. 2006. Trust and Tracing game: learning about transactions and embeddedness in a trade network. Production Planning \& Control, 17, 569-583.

MOHER, D., LIBERATI, A., TETZLAFF, J., ALTMAN, D. G. \& GROUP, P. 2009. Preferred reporting items for systematic reviews and meta-analyses: the PRISMA statement. PLoS medicine, 6, e1000097.

MONTANOLA-SALES, C., ONGGO, B. S. S. \& CASANOVAS-GARCIA, J. Agent-based simulation validation: A case study in demographic simulation. Proceedings of the Third International Conference on Advances in System Simulation (SIMUL 2011), 2011. 109115.

MORGAN, F. J. \& DAIGNEAULT, A. J. 2015. Estimating Impacts of Climate Change Policy on Land Use: An Agent-Based Modelling Approach. PLoS ONE, 10, e0127317.

MORGAN, J. F., BROWN, P. \& DAIGNEAULT, J. A. 2015. Simulation vs. Definition: Differing Approaches to Setting Probabilities for Agent Behaviour. Land, 4.

NAINGGOLAN, D., TERMANSEN, M., FLESKENS, L., HUBACEK, K., REED, M. S., DE VENTE, J. \& BOIXFAYOS, C. 2012. What does the future hold for semi-arid Mediterranean agroecosystems? - Exploring cellular automata and agent-based trajectories of future landuse change. Applied Geography, 35, 474-490.

NG, D. W. 2008. Structural Change in a Food Supply Chain. International Food and Agribusiness Management Review, 11. 
Dhanan Sarwo Utomo, Bhakti Stephan Onggo, Stephen Eldridge, Applications of agent-based modelling and simulation in the agri-food supply chains, In European Journal of Operational Research, 2017, ISSN 0377-2217, https://doi.org/10.1016/j.ejor.2017.10.041.

NOLAN, J., PARKER, D., VAN KOOTEN, G. C. \& BERGER, T. 2009. An Overview of Computational Modeling in Agricultural and Resource Economics. Canadian Journal of Agricultural Economics/Revue canadienne d'agroeconomie, 57, 417-429.

OLABISI, S. L., WANG, Q. R. \& LIGMANN-ZIELINSKA, A. 2015. Why Don't More Farmers Go Organic? Using A Stakeholder-Informed Exploratory Agent-Based Model to Represent the Dynamics of Farming Practices in the Philippines. Land, 4.

OLIVEIRA, J. B., LIMA, R. S. \& MONTEVECHI, J. A. B. 2016. Perspectives and relationships in Supply Chain Simulation: A systematic literature review. Simulation Modelling Practice and Theory, 62, 166-191.

ONGGO, B. S., BUSBY, J. \& LIU, Y. Using agent-based simulation to analyse the effect of broadcast and narrowcast on public perception: A case in social risk amplification. Proceedings of the Winter Simulation Conference 2014, 7-10 Dec. 2014 2014. 322-333.

ONGGO, B. S. \& KARATAS, M. 2016. Test-driven simulation modelling: A case study using agentbased maritime search-operation simulation. European Journal of Operational Research, 254, 517-531.

ONGGO, B. S. S. 2013. Agent-based simulation model representation using BPMN. Formal Languages for Computer Simulation: Transdisciplinary Models and Applications. Hershey, PA: Information Science Reference, 378-399.

OSINGA, S. A., KRAMER, M. R. \& HOFSTEDE, G. J. 2015. Sustainable animal welfare: does forcing farmers into transition help? AI \& SOCIETY, 30, 403-413.

PIDD, M. 2004. Computer simulation in management science, Hoboken, NJ, Hoboken, NJ : Wiley.

PLA, L. M., SANDARS, D. L. \& HIGGINS, A. J. 2014. A perspective on operational research prospects for agriculture. Journal of the Operational Research Society, 65, 1078-1089.

QUANG, D. V., SCHREINEMACHERS, P. \& BERGER, T. 2014. Ex-ante assessment of soil conservation methods in the uplands of Vietnam: An agent-based modeling approach. Agricultural Systems, 123, 108-119.

REIDSMA, P., BAKKER, M. M., KANELLOPOULOS, A., ALAM, S. J., PAAS, W., KROS, J. \& DE VRIES, W. 2015. Sustainable agricultural development in a rural area in the Netherlands? Assessing impacts of climate and socio-economic change at farm and landscape level. Agricultural Systems, 141, 160-173.

ROBINSON, D. T., BROWN, D. G., PARKER, D. C., SCHREINEMACHERS, P., JANSSEN, M. A., HUIGEN, M., WITTMER, H., GOTTS, N., PROMBUROM, P., IRWIN, E., BERGER, T., GATZWEILER, F. \& BARNAUD, C. 2007. Comparison of empirical methods for building agent-based models in land use science. Journal of Land Use Science, 2, 31-55.

ROSS, R. B. 2011. Entrepreneurial behaviour in agri-food supply chains: the role of supply chain partners. Journal on Chain and Network Science, 11, 19-30.

ROSS, R. B. \& WESTGREN, R. E. 2009. An Agent-Based Model of Entrepreneurial Behavior in AgriFood Markets. Canadian Journal of Agricultural Economics/Revue canadienne d'agroeconomie, 57, 459-480.

ROUZAFZOON, J. \& HELO, P. 2016. Developing service supply chains by using agent based simulation. Industrial Management \& Data Systems, 116, 255-270. 
Dhanan Sarwo Utomo, Bhakti Stephan Onggo, Stephen Eldridge, Applications of agent-based modelling and simulation in the agri-food supply chains, In European Journal of Operational Research, 2017, ISSN 0377-2217, https://doi.org/10.1016/j.ejor.2017.10.041.

SARGENT, R. G. 2013. Verification and validation of simulation models. Journal of Simulation, 7, 12-24.

SCHIERITZ, N. \& GROBLER, A. Emergent structures in supply chains-a study integrating agentbased and system dynamics modeling. 2003 2003. IEEE, 9-pp.

SCHOUTEN, M., OPDAM, P., POLMAN, N. \& WESTERHOF, E. 2013. Resilience-based governance in rural landscapes: Experiments with agri-environment schemes using a spatially explicit agent-based model. Land Use Policy, 30, 934-943.

SCHOUTEN, M., VERWAART, T. \& HEIJMAN, W. 2014. Comparing two sensitivity analysis approaches for two scenarios with a spatially explicit rural agent-based model. Environmental Modelling \& Software, 54, 196-210.

SCHREINEMACHERS, P. \& BERGER, T. 2011. An agent-based simulation model of humanenvironment interactions in agricultural systems. Environmental Modelling \& Software, 26, 845-859.

SCHREINEMACHERS, P., BERGER, T. \& AUNE, J. B. 2007. Simulating soil fertility and poverty dynamics in Uganda: A bio-economic multi-agent systems approach. Ecological Economics, 64, 387-401.

SCHREINEMACHERS, P., BERGER, T., SIRIJINDA, A. \& PRANEETVATAKUL, S. 2009. The Diffusion of Greenhouse Agriculture in Northern Thailand: Combining Econometrics and Agent-Based Modeling. Canadian Journal of Agricultural Economics/Revue canadienne d'agroeconomie, 57, 513-536.

SCHREINEMACHERS, P., POTCHANASIN, C., BERGER, T. \& ROYGRONG, S. 2010. Agent-based modeling forex anteassessment of tree crop innovations: litchis in northern Thailand. Agricultural Economics, 41, 519-536.

SMAJGL, A., HOUSE, A. P. N. \& BUTLER, J. R. A. 2011. Implications of ecological data constraints for integrated policy and livelihoods modelling: An example from East Kalimantan, Indonesia. Ecological Modelling, 222, 888-896.

SOBOL', I. M. 2001. Global sensitivity indices for nonlinear mathematical models and their Monte Carlo estimates. Mathematics and Computers in Simulation, 55, 271-280.

SONDEREGGER-WAKOLBINGER, L. M. \& STUMMER, C. 2015. An agent-based simulation of customer multi-channel choice behavior. Central European Journal of Operations Research, 23, 459.

SOTO-SILVA, W. E., NADAL-ROIG, E., GONZÁLEZ-ARAYA, M. C. \& PLA-ARAGONES, L. M. 2016. Operational research models applied to the fresh fruit supply chain. European Journal of Operational Research, 251, 345-355.

TEN BROEKE, G., VAN VOORN, G. \& LIGTENBERG, A. 2016. Which Sensitivity Analysis Method Should I Use for My Agent-Based Model? Journal of Artificial Societies and Social Simulation, 19, 5.

TROOST, C. \& BERGER, T. 2015. Dealing with Uncertainty in Agent-Based Simulation: Farm-Level Modeling of Adaptation to Climate Change in Southwest Germany. American Journal of Agricultural Economics, 97, 833-854. 
Dhanan Sarwo Utomo, Bhakti Stephan Onggo, Stephen Eldridge, Applications of agent-based modelling and simulation in the agri-food supply chains, In European Journal of Operational Research, 2017, ISSN 0377-2217, https://doi.org/10.1016/j.ejor.2017.10.041.

TYKHONOV, D., JONKER, C., MEIJER, S. \& VERWAART, T. 2008. Agent-based simulation of the trust and tracing game for supply chains and networks. Journal of Artificial Societies and Social Simulation, 11, 1.

UDUMYAN, N., ROUCHIER, J. \& AMI, D. 2014. Integration of Path-Dependency in a Simple Learning Model: The Case of Marine Resources. Computational Economics, 43, 199-231.

UTHES, S., PIORR, A., ZANDER, P., BIEŃKOWSKI, J., UNGARO, F., DALGAARD, T., STOLZE, M., MOSCHITZ, H., SCHADER, C., HAPPE, K., SAHRBACHER, A., DAMGAARD, M., TOUSSAINT, V., SATTLER, C., REINHARDT, F.-J., KJELDSEN, C., CASINI, L. \& MÜLLER, K. 2011. Regional impacts of abolishing direct payments: An integrated analysis in four European regions. Agricultural Systems, 104, 110-121.

VAHID, S., LEHOUX, N., DE SANTA-EULALIA, L. A., D'AMOURS, S., FRAYRET, J.-M. \& VENKATADRI, U. 2016. Supply chain modelling frameworks for forest products industry: a systematic literature review. INFOR: Information Systems and Operational Research, 54, 52-75.

VAN DER VORST, J. G. A. J., BEULENS, A. J. M. \& VAN BEEK, P. 2000. Modelling and simulating multi-echelon food systems. European Journal of Operational Research, 122, 354-366.

VAN ECK, N. J. \& WALTMAN, L. 2009. Software survey: VOSviewer, a computer program for bibliometric mapping. Scientometrics, 84, 523-538.

VRABEL, M. Preferred Reporting Items for Systematic Reviews and Meta-Analyses. Oncology nursing forum, 2015. 552-554.

WANG, J., BROWN, D. G., RIOLO, R. L., PAGE, S. E. \& AGRAWAL, A. 2013. Exploratory analyses of local institutions for climate change adaptation in the Mongolian grasslands: An agentbased modeling approach. Global Environmental Change, 23, 1266-1276.

WEBBER, C. M. \& LABASTE, P. 2009. Building competitiveness in Africa's agriculture: a guide to value chain concepts and applications, World Bank Publications.

WORLD BANK. 2016. World Bank Country and Lending Groups [Online]. World Bank. Available: https://datahelpdesk.worldbank.org/knowledgebase/articles/906519.

WORRAPIMPHONG, K., GAJASENI, N., LE PAGE, C. \& BOUSQUET, F. 2010. A companion modeling approach applied to fishery management. Environmental Modelling \& Software, 25, 13341344.

WOSSEN, T. \& BERGER, T. 2015. Climate variability, food security and poverty: Agent-based assessment of policy options for farm households in Northern Ghana. Environmental Science \& Policy, 47, 95-107.

ZHANG, T. \& BRORSEN, B. W. 2010. The Long-Run and Short-Run Impact of Captive Supplies on the Spot Market Price: An Agent-Based Artificial Market. American Journal of Agricultural Economics, 92, 1181-1194.

ZHENG, C., LIU, Y., BLUEMLING, B., CHEN, J. \& MOL, A. P. J. 2013. Modeling the environmental behavior and performance of livestock farmers in China: An ABM approach. Agricultural Systems, 122, 60-72.

ZHENG, C., LIU, Y., BLUEMLING, B., MOL, A. P. J. \& CHEN, J. 2015. Environmental potentials of policy instruments to mitigate nutrient emissions in Chinese livestock production. Science of The Total Environment, 502, 149-156. 
Dhanan Sarwo Utomo, Bhakti Stephan Onggo, Stephen Eldridge, Applications of agent-based modelling and simulation in the agri-food supply chains, In European Journal of Operational Research, 2017, ISSN 0377-2217, https://doi.org/10.1016/j.ejor.2017.10.041.

ZIMMERMANN, A., OUML, HRING, A., MACK, G., FERJANI, A. \& MANN, S. 2015. Pathways to Truth: Comparing Different Upscaling Options for an Agent-Based Sector Model. Journal of Artificial Societies and Social Simulation, 18, 11. 